\title{
PROFIL KEMAMPUAN KONEKSI MATEMATIS DITINJAU DARI KONSEP DIRI MAHASISWA PENDIDIKAN MATEMATIKA
}

\author{
Alfisyahra $^{1)}$, Nurul Inayah ${ }^{2)}$, Welli Meinarni ${ }^{3)}$ \\ alfisyahra27@gmail.com ${ }^{1)}$, inayah.nurulNI@gmail.com ${ }^{2)}$,wellimeinarni91@gmail.com ${ }^{3)}$ \\ Program Studi Pendidikan Matematika, Universitas Tadulako
}

\begin{abstract}
Abstrak: Tujuan penelitian ini yaitu untuk mendeskripsikan profil kemampuan koneksi matematis ditinjau dari konsep diri mahasiswa pendidikan matematika. Jenis penelitian ini adalah penelitian deskriptif dengan pendekatan kualitatif. Pemilihan subjek didasarkan pada sifat konsistensi data yang diperoleh dari suatu subjek dengan mempertimbangkan kategori konsep diri mahasiswa (tinggi, sedang, rendah) dan kemampuan mahasiswa dalam berkomunikasi. Instrumen dalam penelitian ini yaitu: (1) skala konsep diri, (2) tes kemampuan koneksi matematis, dan (3) pedoman wawancara. Proses pengumpulan data dalam penelitian ini dilakukan melalui langkah-langkah: 1) pemberian tes koneksi, 2) verifikasi data melalui wawancara, 3) mereduksi data, abstraksi, transformasi, dan pengkategorian data, 4) melakukan triangulasi metode, dan 5) melakukan penafsiran.Teknik analisa data dalam penelitian ini mengacu pada analisa data kualitatif menurut Miles dan Huberman yang meliputi: 1) reduksi data; 2) penyajian data; 3) penarikan kesimpulan. Hasil penelitian yang diperoleh didasarkan pada indikator kemampuan koneksi matematis subjek yang dilihat dari kemampuan subjek mengaitkan konsep antargagasan dalam matematika, mengaitkan konsep matematika dengan bidang ilmu lain, dan mengaitkan konsep matematika dalam kehidupan sehari-hari.
\end{abstract}

Kata Kunci: Koneksi Matematis, Konsep Diri.

National Council of Teacher of Mathematics (NCTM, 2000) mengemukakan salah satu pentingnya pembelajaran matematika, yaitu belajar mengaitkan ide (mathematical connection). Hal ini sesuai dengan pernyataan Badan Standar Nasional Pendidikan (BSNP) (2006) bahwa setiap jenjang pendidikan perlu diberikan mata pelajaran matematika agar siswa memiliki kemampuan dalam menjelaskan keterkaitan antarkonsep dan mengaplikasikan konsep tersebut secara luwes, akurat, efisien, dan tepat dalam pemecahan masalah.

Kemampuan koneksi matematis merupakan kemampuan peserta didik dalam memahami materi matematika yang lebih kompleks. Peserta didik akan menemui kesulitan dalam menyelesaikan permasalahan matematika tanpa memiliki kemampuan koneksi yang baik, sebab matematika merupakan satu kesatuan, dimana konsep yang satu berhubungan dengan konsep yang lain. Rahmawati, dkk (2018) menyatakan bahwa konsep pemikiran dan wawasan peserta didik terhadap matematika akan semakin lebih luas melalui proses koneksi. Apabila peserta didik memiliki wawasan yang luas, maka peserta didik akan memiliki kemampuan untuk menyelesaikan soal-soal matematika yang lebih kompleks. Lasmanawati (2011) mengungkapkan bahwa melalui koneksi 71 matematis, wawasan peserta didik akan semakin terbuka terhadap matematika, yang kemudian akan menimbulkan sikap positif terhadap matematika. 
Alberta Education (2007) menyatakan bahwa untuk mencapai tujuan pendidikan matematika, salah satunya adalah melalui pengembangan kemampuan koneksi matematis peserta didik yang meliputi kemampuan menghubungkan ide-ide matematika dengan konsep lain dalam matematika, dengan pengalaman sehari-hari dan dengan disiplin ilmu lain. Hal serupa juga dikemukakan oleh Coxford (1995) bahwa kemampuan matematis merupakan kemampuan menghubungkan pengetahuan konseptual dan prosedural, menggunakan matematika pada topik lain, menggunakan matematika dalam aktivitas kehidupan, mengetahui koneksi antar topik dalam matematika. Pendapat-pendapat tersebut menunjukkan bahwa matematika tidak berdiri sendiri, namun berkaitan dengan konteks di luar matematika, baik berhubungan dengan disiplin ilmu yang lain atau dengan kehidupan nyata. Bruner (1977) mengungkapkan bahwa dalam matematika, antara satu konsep dengan konsep lain terdapat hubungan yang erat, bukan saja dari segi isi, namun juga dari segi rumus-rumus yang digunakan. Oleh karena itu, agar siswa dapat berhasil dalam belajarnya maka siswa harus berlatih mengkoneksikan konsep-konsep dalam matematika itu sendiri maupun konteks di luar matematika.

Namun kenyataannya, daya tangkap peserta didik berbeda dengan peserta didik lainnya terhadap matematika. Hal ini disebabkan adanya faktor-faktor berbeda yang mempengaruhi pola berpikir setiap individu. Gage \& Berlier (1984) mengemukakan bahwa faktor yang mempengaruhi prestasi atau hasil belajar adalah faktor dari dalam siswa dan faktor dari luar diri siswa. Hal serupa dikemukakan oleh Suryabrata (2012: 233) bahwa faktor-faktor yang mempengaruhi hasil belajar dapat diklasifikasikan menjadi dua, yaitu faktor internal, meliputi faktor fisiologis dan psikologis; faktor eksternal meliputi faktor sosial dan nonsosial. Berdasarkan kedua pendapat tersebut, nampaknya aspek psikologis memberikan kontribusi yang cukup signifikan terhadap keberhasilan seseorang dalam menyelesaikan tugas dengan baik.

Callhoun \& Acocella (Ghufron \& Risnawati, 2010) mengklasifikasikan perkembangan konsep diri terbagi menjadi dua jenis, yaitu konsep diri positif dan konsep diri negatif. Syam (2012) menyatakan bahwa apabila seseorang memiliki konsep diri positif, maka ia akan cenderung optimis, sehingga tidak mudah menyerah dan merasa mampu menyelesaikan permasalahan yang sedang atau akan dihadapinya. Sebaliknya, apabila seseorang memiliki konsep diri negatif, maka ia akan cenderung pesimis, sehingga mudah menyerah dan merasa tidak mampu menyelesaikan permasalahan yang sedang dihadapinya. Berkaitan dengan matematika, disimpulkan bahwa konsep diri akan mempengaruhi kemampuan peserta didik dalam belajar matematika, termasuk didalamnya kemampuan melakukan koneksi matematis. Tujuan penelitian ini untuk mendeskripsikan profil kemampuan koneksi matematis ditinjau dari konsep diri mahasiswa pendidikan matematika.

\section{METODE PENELITIAN}

Jenis penelitian ini adalah penelitian deskriptif dengan pendekatan kualitatif yang bertujuan untuk menjelaskan profil kemampuan koneksi matematis ditinjau dari konsep diri mahasiswa pendidikan matematika. Subyek dalam penelitian ini adalah mahasiswa Program Studi Pendidikan Matematika angkatan 2019 Fakultas Keguruan dan Ilmu Pendidikan, Universitas Tadulako. Pemilihan subjek didasarkan pada sifat konsistensi data yang diperoleh 
dari suatu subjek dengan mempertimbangkan kategori konsep diri mahasiswa (tinggi, sedang, rendah) dan kemampuan mahasiswa dalam berkomunikasi. Instrumen utama dalam penelitian ini adalah adalah peneliti sendiri, sedangkan instrumen pendukungnya yaitu: (1) skala konsep diri, (2) tes kemampuan koneksi matematis, dan (3) pedoman wawancara. Proses pengumpulan data dalam penelitian ini dilakukan melalui langkah-langkah: 1) pemberian tes koneksi, 2) verifikasi data melalui wawancara, 3) mereduksi data, abstraksi, transformasi, dan pengkategorian data, 4) melakukan triangulasi metode, dan 5) melakukan penafsiran. Teknik analisa data dalam penelitian ini mengacu pada analisa data kualitatif menurut Miles dan Huberman (Sugiyono, 2013) yang meliputi: 1) reduksi data; 2) penyajian data; 3) penarikan kesimpulan.

\section{HASIL PENELITIAN}

Subjek penelitian ditentukan berdasarkan hasil analisis tes konsep diri mahasiswa yang dilakukan dengan cara mengelompokkan hasil tes konsep diri mahasiswa menjadi 3 kategori yakni tinggi, sedang, dan rendah. Dari masing-masing kategori tersebut kemudian ditentukan satu orang mahasiswa untuk menjadi subjek penelitian. Penentuan subjek penelitian juga dilakukan dengan mempertimbangkan hal lain berupa kemampuan berkomunikasi mahasiswa dan kesediaan subjek berpartisipasi dalam pengambilan data selama penelitian.

Guna mengetahui kemampuan koneksi matematis mahasiswa dalam menyelesaikan soal pemecahan masalah pada materi kalkulus maka peneliti memberi dua buah soal pemecahan masalah yang diberi kode TKM1 untuk soal nomor 1 dan TKM2 untuk soal nomor 2. Adapun analisis kemampuan koneksi matematis subjek dalam memecahkan masalah yang diberikan dipaparkan pada Tabel 1 berikut:

Tabel 1. Data Kemampuan Subjek dalam Memecahkan Masalah

\begin{tabular}{|c|c|c|}
\hline Subjek Tinggi & Subjek Sedang & Subjek Rendah \\
\hline $\begin{array}{l}\text { Dalam mengenali hubungan- } \\
\text { hubungan antara gagasan dalam } \\
\text { matematika, subjek terlebih } \\
\text { dahulu mengumpulkan data } \\
\text { dengan menyebutkan unsur- } \\
\text { unsur yang diketahui dan } \\
\text { ditanyakan. Lebih lanjut dalam } \\
\text { memanfaatkan hubungan- } \\
\text { hubungan gagasan matematika, } \\
\text { subjek menggunakan beberapa } \\
\text { konsep matematika untuk } \\
\text { menyelesaikan tes kemampuan } \\
\text { koneksi yakni konsep turunan } \\
\text { dan integral serta konsep } \\
\text { bilangan bulat dengan metode } \\
\text { substitusi. }\end{array}$ & $\begin{array}{l}\text { Dalam mengenali hubungan- } \\
\text { hubungan antara gagasan dalam } \\
\text { matematika, subjek menggunakan } \\
\text { konsep turunan a= yang menjadi } \\
\text { dasar subjek untuk melakukan } \\
\text { pengintegralan. Selain itu, subjek } \\
\text { menggunakan aturan penjumlahan } \\
\text { dan perkalian untuk memperoleh } \\
\text { kecepatan awal (v0) }\end{array}$ & $\begin{array}{l}\text { Dalam mengenali dan } \\
\text { memanfaatkan } \\
\text { hubunganhubungan antara } \\
\text { gagasan dalam matematika, } \\
\text { subjek menggunakan } \\
\text { aturan penjumlahan dan } \\
\text { perkalian untuk } \\
\text { memperoleh kecepatan } \\
\text { awal (v0). Subjek juga } \\
\text { menggunakan aturan } \\
\text { integral untuk memperoleh } \\
\text { kecepatan }\end{array}$ \\
\hline
\end{tabular}




Dalam memanfaatkan hubungan
antara gagasan matematika
dengan gagasan pada bidang
ilmu lain, subjek menggunakan
konsep jarak, waktu, kecepatan,
dan percepatan yang merupakan
konsep pada pelajaran fisika

Dalam mengenali hubungan antara gagasan matematika dengan kehidupan seharihari, subjek mengungkapkan hal-hal yang berkaitan dengan kehidupan sehari-hari yang bisa diselesaikan menggunakan konsep integral.

\begin{abstract}
Dalam memanfaatkan hubungan antara gagasan matematika dengan gagasan pada bidang ilmu lain, subjek menggunakan salah satu konsep pada mata pelajaran fisika dengan menghubungkan nilai percepatan pada rumus gerak lurus berubah beraturan (GLBB).
\end{abstract}

\author{
Dalam mengenali dan \\ memanfaatkan hubungan \\ antara gagasan matematika \\ dengan bidang ilmu lain, \\ subjek menggunakan \\ rumus GLBB dalam fisika, \\ namun subjek hanya \\ mengatakan bahwa soal ini \\ berkaitan dengan konsep \\ kelajuan, kecepatan, dan \\ percepatan.
}

Dalam mengenali hubungan antara gagasan matematika dengan kehidupan seharihari, subjek mengungkapkan hal-hal yang berkaitan dengan kehidupan seharihari yang bisa diselesaikan menggunakan konsep integral.

\section{PEMBAHASAN}

Dalam mengenali dan menghubungkan gagasan-gagasan antar konsep matematika, subjek dengan kategori konsep diri tinggi mampu mengenali dan menghubungkan gagasan-gagasan antar konsep matematika dengan menggunakan aturan turunan dan integral. Subjek dapat melakukan koneksi dengan baik karena subjek memiliki konsep diri yang tinggi sebagai esensi dalam pembelajaran matematika yaitu dapat membekali peserta didik untuk berpikir logis, analitis, sistematis, kritis, dan kreatif. Hal ini sesuai dengan pendapat Syam (2012) yang menyatakan bahwa apabila seseorang memiliki konsep diri positif, maka ia akan cenderung optimis, sehingga tidak mudah menyerah dan merasa mampu menyelesaikan permasalahan yang sedang atau akan dihadapinya. Hal ini sejalan pula dengan hasil penelitian Setiawan dan Waspodo (2015) bahwa konsep diri memiliki hubungan yang positif terhadap hasil belajar matematika. Subjek dengan kategori konsep diri juga tidak terpaku pada satu jenis penyelesaian saja, tetapi mampu mencari jalan keluar lain untuk menyelesaikan permasalahan. Hal ini sejalan dengan hasil penelitian Nurafni dan Pujiastuti (2019) yang memberikan kesimpulan bahwa peserta didik yang memiliki kepercayaan diri tinggi memiliki kemampuan koneksi matematis yang sangat baik dalam aspek memahami konsep matematika dengan mata pelajaran lain.

Selain dua indikator koneksi yang telah dijelaskan di atas, subjek dengan konsep diri tinggi mampu mengenali dan menghubungkan gagasan matematika dengan kehidupan sehari-hari. Hal ini sejalan dengan hasil penelitian dari Nurafni dan Pujiastuti (2019) yang memberikan kesimpulan bahwa peserta didik dengan kelompok kepercayaan diri tinggi memiliki kemampuan koneksi matematis yang sangat baik dalam aspek memahami konsep matematika dalam kehidupan sehari-hari. 
Subjek dengan kategori konsep diri sedang, kurang mampu mengenali dan menghubungkan gagasan-gagasan antar konsep matematika, dalam hal ini subjek tidak dapat mengaitkan konsep integral dan turunan yang diberikan pada tes koneksi matematis, tetapi subjek hanya dapat melihat adanya hubungan operasi penjumlahan, perkalian, dan pembagian untuk menyelesaikan soal

tersebut. Subjek mampu mengenali dan menghubungkan konsep matematika dengan bidang ilmu lain, yaitu konsep gerak lurus berubah beraturan yang dipelajari dalam pelajaran fisika; Serta subjek mampu mengenali dan menghubungkan gagasan matematika dengan kehidupan sehari-hari. Hal ini sejalan dengan hasil penelitian Nurafni dan Pujiastuti (2019) yang menyatakan bahwa peserta didik dengan kelompok konsep diri sedang memiliki kemampuan koneksi yang baik dalam aspek memahami konsep matematika dalam kehidupan sehari-hari.

Subjek dengan kategori konsep diri rendah, kurang mampu mengenali dan menghubungkan gagasan-gagasan antar konsep matematika. Dalam hal ini subjek tidak dapat mengaitkan konsep integral dan turunan yang diberikan pada tes koneksi matematis, tetapi subjek hanya dapat melihat adanya hubungan operasi penjumlahan, perkalian, dan pembagian untuk menyelesaikan soal tersebut. Subjek mampu melihat adanya hubungan tes yang diberikan dengan konsep integral, namun subjek tidak dapat menyelesaikan soal dengan konsep integral tersebut. Hal ini sejalan dengan pendapat Syam (2012) yang menyatakan bahwa apabila seseorang memiliki konsep diri negatif, maka ia akan cenderung pesimis, sehingga mudah menyerah dan merasa tidak mampu menyelesaikan permasalahan yang sedang dihadapinya. Hal ini sejalan dengan hasil penelitian Nurafni dan Pujiastuti (2019) yang menyatakan bahwa peserta didik dengan kelompok konsep diri rendah memiliki kemampuan koneksi yang sangat kurang dalam aspek memahami konsep antar topik matematika.

Subjek mampu mengenali dan menghubungkan konsep matematika dengan bidang ilmu lain, yaitu konsep gerak lurus berubah beraturan yang dipelajari dalam pelajaran fisika. Selain dua indikator kemampuan koneksi matematis yang telah dipaparkan sebelumnya, subjek kurang mampu mengenali dan menghubungkan gagasan matematika dengan kehidupan seharihari. Hal ini sejalan dengan hasil penelitian Nurafni dan Pujiastuti (2019) yang menyatakan bahwa peserta didik dengan kelompok konsep diri rendah memiliki kemampuan koneksi yang cukup dalam aspek memahami konsep matematika dalam kehidupan sehari-hari.

\section{KESIMPULAN}

1. Subjek dengan kategori konsep diri tinggi, mampu mengenali dan menghubungkan gagasan-gagasan antar konsep matematika, yaitu aturan turunan dan integral; mampu mengenali dan menghubungkan konsep matematika dengan bidang ilmu lain, yaitu konsep jarak, kecepatan, dan percepatan yang dipelajari dalam pelajaran fisika; serta mampu mengenali dan menghubungkan gagasan matematika dengan kehidupan sehari-hari.

2. Subjek dengan kategori konsep diri sedang, kurang mampu mengenali dan menghubungkan gagasan-gagasan antar konsep matematika, dalam hal ini subjek tidak dapat mengaitkan konsep integral dan turunan yang diberikan pada tes koneksi matematis, tetapi subjek hanya dapat melihat adanya hubungan operasi penjumlah, perkalian, dan pembagian untuk menyelesaikan soal tersebut; Subjek mampu mengenali dan 
98 AKSIOMA, Volume 10 Nomor 2, September 2021

menghubungkan konsep matematika dengan bidang ilmu lain, yaitu konsep gerak lurus berubah beraturan yang dipelajari dalam pelajaran fisika; Serta subjek mampu mengenali dan menghubungkan gagasan matematika dengan kehidupan sehari-hari.

3. Subjek dengan kategori konsep diri rendah, kurang mampu mengenali dan menghubungkan gagasan-gagasan antar konsep matematika, dalam hal ini subjek tidak dapat mengaitkan konsep integral dan turunan yang diberikan pada tes koneksi matematis, tetapi subjek hanya dapat melihat adanya hubungan operasi penjumlah, perkalian, dan pembagian untuk menyelesaikan soal tersebut, subjek mampu melihat adanya hubungan tes yang diberikan dengan konsep integral, namun subjek tidak dapat menyelesaikan soal dengan konsep integral tersebut; Subjek mampu mengenali dan menghubungkan konsep matematika dengan bidang ilmu lain, yaitu konsep gerak lurus berubah beraturan yang dipelajari dalam pelajaran fisika; Serta subjek kurang mampu mengenali dan menghubungkan gagasan matematika dengan kehidupan sehari-hari.

\section{SARAN}

Berdasarkan hal-hal yang terjadi pada saat penelitian, maka peneliti dapat menyarankan hal-hal berikut.

1. Perlu bagi peneliti pihak lain yang ingin melakukan penelitian yang serupa untuk mengaitkan gagasan matematika dengan beberapa ilmu terkait, tidak hanya kepada satu bidang ilmu saja.

2. Perlu bagi peneliti pihak lain untuk mengembangkan instrumen yang akan digunakan dalam mengukur kemampuan subjek penelitian.

3. Perlu bagi peneliti pihak lain untuk menambahkan variabel penelitian agar hasil penelitian yang diperoleh menjadi lebih berkualitas, baik dari segi isi maupun cakupan penelitian

\section{DAFTAR PUSTAKA}

Bandung National Council of Teachers of Mathematics. (2000). Principles and Standards for School Mathematics (online): https://investigations.terc.edu/library/ components/ principles_standards.pdf diakses pada tanggal 26 Februari 2020.

Lasmanawati. (2011). Pengaruh Pembelajaran Menggunakan Pendekatan Proses Berpikir Reflektif Terhadap Peningkatan Kemampuan Koneksi dan Berpikir Kritis Matematis Siswa. UPI.

Gage, N.L \& Berlier, D.C. (1984). Educational Psychology. (Third Edition). Boston: Hougton Mifflin Company.

Ghufron \& Risnawati, Rini. (2010). Teori-teori Psikologi. Yogyakarta: Ar-Ruzz Media

Nurafni, Atika., Pujiastuti, Heni. 2019. Analisis Kemampuan Koneksi Matematis Ditinjau dari Self-Confidence Siswa: Studi Kasus di SMKN 4 Pandeglang. Jurnal Ilmiah Pendidikan Matematika, Vol.2 No. 1, April 2019. (online) : file:///C:/Users/sony/Downloads/301311171-1-PB.pdf diakses pada tanggal 11 November 2020 
Rahmawati, Yulia. Priatna, Nunung. Nurjannah. (2018). Meningkatkan Kemampuan Koneksi Matematis dan Self-Concept Siswa Melalui Pendekatan Saintifik pada Materi Trigonometri. Jurnal Matematika dan Pendidikan Matematika Vol. 3 No. 2, Bulan September 2018. (online): http://journal.unipdu.ac.id:8080/index.php/ jmpm/article /download/1272/856 diakses pada tanggal 26 Februari 2020

Setiawan, Anto Indra., Waspodo, Muktiono. 2015. Hubungan Antara Gaya Belajar dan Konsep Diri dengan Hasil Belajar Matematika. Jurnal teknologi Pendidikan Vol. 4 Nomor 2, Tahun 2015 (online): https://core.ac.uk/download/pdf/230806675.pdf diakses pada tanggal 11 November 2020.

Sugiyono. 2013. Metode Penelitian Kuantitatif, Kualitatif, dan R\&D. Bandung: CV. Alfabeta.

Syam, Nina W. (2012). Psikologi Sosial sebagai Akar Ilmu Komunikasi. Bandung: Simbiosa Rekatama Media 